\title{
INEQUALITIES OF HERMITE-HADAMARD TYPE FOR FUNCTIONS OF SELFADJOINT OPERATORS AND MATRICES
}

\author{
Silvestru SEVER DRAGOMIR
}

Abstract. Some inequalities of Hermite-Hadamard type for operator convex functions in Hilbert spaces are given. The case for matrices and convex functions is also considered. Examples for some particular functions of interest are provided as well.

Mathematics subject classification (2010): 26D15, 25D10.

Keywords and phrases: Convex functions, trace inequalities, Hermite-Hadamard inequality, selfadjoint operators, Hermitian matrices.

\section{REFERENCES}

[1] M. Alomari and M. Darus, The Hadamard's inequality for s-convex function, Int. J. Math. Anal. (Ruse) 2 (2008), no. 13-16, 639-646.

[2] M. Alomari And M. Darus, Hadamard-type inequalities for s-convex functions, Int. Math. Forum 3 (2008), no. 37-40, 1965-1975.

[3] G. A. Anastassiou, Univariate Ostrowski inequalities, revisited, Monatsh. Math., 135 (2002), no. 3, 175-189.

[4] N. S. Barnett, P. Cerone, S. S. Dragomir, M. R. Pinheiro, and A. Sofo, Ostrowski type inequalities for functions whose modulus of the derivatives are convex and applications, Inequality Theory and Applications, Vol. 2 (Chinju/Masan, 2001), 19-32, Nova Sci. Publ., Hauppauge, NY, 2003, preprint: RGMIA Res. Rep. Coll. 5 (2002), no. 2, Art. 1, online http://rgmia.org/papers/v5n2/Paperwapp2q.pdf.

[5] E. F. Beckenbach, Convex functions, Bull. Amer. Math. Soc. 54 (1948), 439-460.

[6] M. Bombardelli And S. Varošanec, Properties of $h$-convex functions related to the HermiteHadamard-Fejér inequalities, Comput. Math. Appl. 58 (2009), no. 9, 1869-1877.

[7] W. W. BRECKNER, Stetigkeitsaussagen für eine Klasse verallgemeinerter konvexer Funktionen in topologischen linearen Räumen, (German) Publ. Inst. Math. (Beograd) (N. S.) 23 (37) (1978), 13-20.

[8] W. W. BRECKNER AND G. ORBÁN, Continuity properties of rationally $s$-convex mappings with values in an ordered topological linear space, Universitatea "Babeş-Bolyai", Facultatea de Matematica, Cluj-Napoca, 1978. viii+92 pp.

[9] P. Cerone And S. S. Dragomir, Midpoint-type rules from an inequalities point of view, Ed. G. A. Anastassiou, Handbook of Analytic-Computational Methods in Applied Mathematics, CRC Press, New York, 135-200.

[10] P. Cerone And S. S. Dragomir, New bounds for the three-point rule involving the RiemannStieltjes integrals, in Advances in Statistics Combinatorics and Related Areas, C. Gulati, et al. (Eds.), World Science Publishing, 2002, 53-62.

[11] P. Cerone, S. S. Dragomir And J. Roumeliotis, Some Ostrowski type inequalities for $n$-time differentiable mappings and applications, Demonstratio Mathematica, 32 (2) (1999), 697-712.

[12] G. CRistescu, Hadamard type inequalities for convolution of h-convex functions, Ann. Tiberiu Popoviciu Semin. Funct. Equ. Approx. Convexity 8 (2010), 3-11.

[13] S. S. DRAGOMIR, Ostrowski's inequality for monotonous mappings and applications, J. KSIAM, 3 (1) (1999), 127-135.

[14] S. S. DRAGOMIR, The Ostrowski's integral inequality for Lipschitzian mappings and applications, Comp. Math. Appl., 38 (1999), 33-37. 
[15] S. S. Dragomir, On the Ostrowski's inequality for Riemann-Stieltjes integral, Korean J. Appl. Math., 7 (2000), 477-485.

[16] S. S. DRAGOMIR, On the Ostrowski's inequality for mappings of bounded variation and applications, Math. Ineq. \& Appl., 4 (1) (2001), 33-40.

[17] S. S. DRAGOMIR, On the Ostrowski inequality for Riemann-Stieltjes integral $\int_{a}^{b} f(t) d u(t)$ where $f$ is of Hölder type and $u$ is of bounded variation and applications, J. KSIAM, 5 (1) (2001), 35-45.

[18] S. S. DRAGomir, Ostrowski type inequalities for isotonic linear functionals, J. Inequal. Pure \& Appl. Math., 3 (5) (2002), Art. 68.

[19] S. S. DRAGOMIR, An inequality improving the first Hermite-Hadamard inequality for convex functions defined on linear spaces and applications for semi-inner products, J. Inequal. Pure Appl. Math. 3 (2002), no. 2, Article 31, 8 pp.

[20] S. S. DRAGOMIR, An inequality improving the first Hermite-Hadamard inequality for convex functions defined on linear spaces and applications for semi-inner products, J. Inequal. Pure Appl. Math. 3 (2002), no. 2, Article 31.

[21] S. S. DRAGOMIR, An inequality improving the second Hermite-Hadamard inequality for convex functions defined on linear spaces and applications for semi-inner products, J. Inequal. Pure Appl. Math. 3 (2002), no. 3, Article 35.

[22] S. S. DRAgomir, An Ostrowski like inequality for convex functions and applications, Revista Math. Complutense, 16 (2) (2003), 373-382.

[23] S. S. DRAGOMIR, Grïss' type inequalities for functions of selfadjoint operators in Hilbert spaces, Ital. J. Pure Appl. Math. No. 28 (2011), 207-224.

[24] S. S. DRAGOMIR, Some new Grüss' type Inequalities for functions of selfadjoint operators in Hilbert spaces, Sarajevo J. Math. 6 (18), 1 (2010), 89-107.

[25] S. S. DRAGOMIR, Some reverses of the Jensen inequality for functions of selfadjoint operators in Hilbert spaces, J. Inequal. Appl. 2010, Art. ID 496821, 15 pp.

[26] S. S. DRAGOMIR, Hermite-Hadamard's type inequalities for convex functions of selfadjoint operators in Hilbert spaces, Linear Algebra Appl. 436 (2012), no. 5, 1503-1515.

[27] S. S. Dragomir, Operator Inequalities of the Jensen, Čebyšev and Grüss Type, Springer Briefs in Mathematics, Springer, New York, 2012. xii+121 pp. ISBN: 978-1-4614-1520-6.

[28] S. S. Dragomir, Operator Inequalities of Ostrowski and Trapezoidal Type, Springer Briefs in Mathematics, Springer, New York, 2012. x+112 pp. ISBN: 978-1-4614-1778-1.

[29] S. S. Dragomir, P. Cerone, J. Roumeliotis and S. WANG, A weighted version of Ostrowski inequality for mappings of Hölder type and applications in numerical analysis, Bull. Math. Soc. Sci. Math. Romanie, 42 (90) (4) (1999), 301-314.

[30] S. S. DRAGOMIR AND S. FitZPATRICK, The Hadamard inequalities for s-convex functions in the second sense, Demonstratio Math. 32 (1999), no. 4, 687-696.

[31] S. S. DRAGOMIR AND S. FitZPATRICK, The Jensen inequality for s-Breckner convex functions in linear spaces, Demonstratio Math. 33 (2000), no. 1, 43-49.

[32] S. S. DRAGOmiR AND B. Mond, On Hadamard's inequality for a class of functions of Godunova and Levin, Indian J. Math. 39 (1997), no. 1, 1-9.

[33] S. S. Dragomir And C. E. M. Pearce, On Jensen's inequality for a class of functions of Godunova and Levin, Period. Math. Hungar. 33 (1996), no. 2, 93-100.

[34] S. S. Dragomir and C. E. M. Pearce, Quasi-convex functions and Hadamard's inequality, Bull. Austral. Math. Soc. 57 (1998), 377-385.

[35] S. S. Dragomir, J. PeČarić And L. Persson, Some inequalities of Hadamard type, Soochow J. Math. 21 (1995), no. 3, 335-341.

[36] S. S. Dragomir And Th. M. Rassias (Eds), Ostrowski Type Inequalities and Applications in Numerical Integration, Kluwer Academic Publisher, 2002.

[37] S. S. DRAGOMIR AND S. WANG, A new inequality of Ostrowski's type in $L_{1}-$ norm and applications to some special means and to some numerical quadrature rules, Tamkang J. of Math., 28 (1997), 239-244.

[38] S. S. DRAGOMIR AND S. WANG, Applications of Ostrowski's inequality to the estimation of error bounds for some special means and some numerical quadrature rules, Appl. Math. Lett., 11 (1998), 105-109. 
[39] S. S. DRAgomir AND S. WANG, A new inequality of Ostrowski's type in $L_{p}$-norm and applications to some special means and to some numerical quadrature rules, Indian J. of Math., 40 (3) (1998), 245-304.

[40] A. EL FARISSI, Simple proof and refeinment of Hermite-Hadamard inequality, J. Math. Ineq. 4 (2010), no. 3, 365-369.

[41] T. Furuta, J. Mićić Hot, J. PečARIĆ And Y. Seo, Mond-Pečarić Method in Operator Inequalities. Inequalities for Bounded Selfadjoint Operators on a Hilbert Space, Element, Zagreb, 2005.

[42] E. K. Godunova And V. I. LEVIn, Inequalities for functions of a broad class that contains convex, monotone and some other forms of functions, (Russian), Numerical mathematics and mathematical physics (Russian), 138-142, 166, Moskov. Gos. Ped. Inst., Moscow, 1985.

[43] H. Hudzik And L. Maligranda, Some remarks on s-convex functions, Aequationes Math. 48 (1994), no. 1, 100-111.

[44] E. Kikianty And S. S. Dragomir, Hermite-Hadamard's inequality and the p-HH-norm on the Cartesian product of two copies of a normed space, Math. Inequal. Appl. (in press).

[45] U. S. Kirmaci, M. Klaričić Bakula, M. E. ÖZdemir And J. PeČArić, Hadamard-type inequalities for s-convex functions, Appl. Math. Comput. 193 (2007), no. 1, 26-35.

[46] M. A. LATIF, On some inequalities for h-convex functions, Int. J. Math. Anal. (Ruse) 4 (2010), no. 29-32, 1473-1482.

[47] A. Matković, J. PeČArić And I. Perić, A variant of Jensen's inequality of Mercer's type for operators with applications, Linear Algebra Appl. 418 (2006), no. 2-3, 551-564.

[48] J. Mićić, Y. Seo, S.-E. TAKAhasi And M. Tominaga, Inequalities of Furuta and Mond-Pečarić, Math. Ineq. Appl., 2 (1999), 83-111.

[49] D. S. Mitrinović And I. B. LACKović, Hermite and convexity, Aequationes Math. 28 (1985), 229-232.

[50] B. Mond AND J. PEČARIĆ, Convex inequalities in Hilbert space, Houston J. Math., 19 (1993), 405420 .

[51] B. Mond And J. PEČARIĆ, On some operator inequalities, Indian J. Math., 35 (1993), 221-232.

[52] B. Mond AND J. PEČARIĆ, Classical inequalities for matrix functions, Utilitas Math., 46 (1994), $155-166$.

[53] C. E. M. Pearce And A. M. Rubinov, P-functions, quasi-convex functions, and Hadamard-type inequalities, J. Math. Anal. Appl. 240 (1999), no. 1, 92-104.

[54] J. E. PEČARIĆ AND S. S. DRAGOMIR, On an inequality of Godunova-Levin and some refinements of Jensen integral inequality, Itinerant Seminar on Functional Equations, Approximation and Convexity (Cluj-Napoca, 1989), 263-268, preprint, 89-6, Univ. "Babeş-Bolyai", Cluj-Napoca, 1989.

[55] J. PEČARIĆ AND S. S. DRAGOMIR, A generalization of Hadamard's inequality for isotonic linear functionals, Radovi Mat. (Sarajevo) 7 (1991), 103-107.

[56] M. Radulescu, S. Radulescu And P. Alexandrescu, On the Godunova-Levin-Schur class of functions, Math. Inequal. Appl. 12 (2009), no. 4, 853-862.

[57] M. Z. Sarikaya, A. Saglam, And H. Yildirim, On some Hadamard-type inequalities for $h$ convex functions, J. Math. Inequal. 2 (2008), no. 3, 335-341.

[58] E. SET, M. E. ÖZDEMIR AND M. Z. SARIKAYA, New inequalities of Ostrowski's type for s-convex functions in the second sense with applications, Facta Univ. Ser. Math. Inform. 27 (2012), no. 1, 67-82.

[59] M. Z. SARIKAYA, E. SET AND M. E. ÖZDEMIR, On some new inequalities of Hadamard type involving $h$-convex functions, Acta Math. Univ. Comenian. (N. S.) 79 (2010), no. 2, 265-272.

[60] M. TUNÇ, Ostrowski-type inequalities via $h$-convex functions with applications to special means, J. Inequal. Appl. 2013, 2013:326.

[61] S. VArošanec, On h-convexity, J. Math. Anal. Appl. 326 (2007), no. 1, 303-311. 